\title{
Characterization and quantification of alveolar monocyte-like cells in human chronic inflammatory lung disease
}

\author{
F. Krombach*, J.T. Gerlach*, C. Padovan*, A. Burges*, J. Behr**, \\ T. Beinert**, C. Vogelmeier**
}

Characterization and quantification of alveolar monocyte-like cells in human chronic inflammatory lung disease. F. Krombach, J.T. Gerlach, C. Padovan, A. Burges, J. Behr, T. Beinert, C. Vogelmeier. CERS Journals Ltd 1996.

ABSTRACT: This flow cytometric study was designed to identify, characterize and quantify alveolar monocyte-like cells in healthy volunteers and in patients with chronic inflammatory lung disease.

Cells were obtained by bronchoalveolar lavage (BAL) from 19 patients with sarcoidosis, 29 with idiopathic pulmonary fibrosis, 10 with extrinsic allergic alveolitis, 19 with collagen vascular disease, and from 10 healthy volunteers. By taking advantage of the distinct electro-optical features of alveolar macrophages (AMs) and monocyte-like cells, the numbers of alveolar monocyte-like cells were counted, the cell dimensions calculated, and the densities of antigens on the surface of alveolar monocyte-like cells and AMs were compared. By using a panel of monoclonal antibodies detecting CD11b, CD14, CD16, and human leucocyte antigen-DR (HLA-DR), the immunophenotypes of these cells were selectively characterized.

In the BAL fluid of patients with chronic inflammatory lung disease, significantly increased numbers of alveolar monocyte-like cells were detected that exhibited an immunophenotype intermediate between blood monocytes and mature AMs. Positive correlations were found between numbers of monocyte-like cells and expression of the monocyte-associated surface antigens CD11b and CD14 on total AMs; in contrast, an inverse relationship existed between monocyte numbers and expression of the macrophage-associated surface antigens CD16 and HLA-DR. When the patients were assigned to two groups according to the percentage of BAL monocyte-like cells being lower or higher than $13 \%$ (=mean value of the controls $+2 \mathrm{sD})$, it could be demonstrated that a high percentage of BAL monocyte-like cells was associated with significantly reduced lung function parameters.

In summary, our flow cytometric data strongly support the view that considerable numbers of blood monocytes are recruited to the bronchoalveolar space in patients with chronic inflammatory lung disease.

Eur Respir J., 1996, 9, 984-991.
*Institute for Surgical Research and **Section for Pulmonary Diseases, Dept of Internal Medicine I, Klinikum Grosshadern, University of Munich, Munich, Germany.

Correspondence: F. Krombach

Institut für Chirurgische Forschung

Klinikum Grosshadern

Marchioninistr. 15

D-81366 München

Germany

Keywords: Adhesion molecules

bronchoalveolar lavage fluid cytology

flow cytometry

interstitial lung diseases

macrophages

monocytes

Received: June 271995

Accepted after revision January 141996
Chronic inflammatory lung diseases are characterized by the presence of an alveolitis that causes a derangement of alveolar structures and ultimately leads to loss of functional gas units. This progressive respiratory failure is thought to result from a disease process that is characterized by the infiltration of inflammatory cells, the increased proliferation of interstitial fibroblasts, and the excessive accumulation of extracellular matrix compounds [1]. Studies on the molecular events leading to pulmonary fibrosis have generally shown that monocytes/macrophages contribute significantly to the disease process [2]. Alveolar macrophages (AMs) are the predominant population of free lung cells in the healthy lung. They represent a heterogeneous group of cells with respect to morphology, immunophenotype and function [3-5]. Under noninflammatory conditions, AMs are thought to be maintained both by local proliferation of resident pulmonary macrophages and extravasation of circulating, bone marrow-derived monocytes $[6,7]$. In lung inflammation, however, it has been suggested that increased numbers of monocytes extravasate from the pulmonary microvasculature to the bronchoalveolar space $[8,9]$.

The alveolitis in interstitial lung diseases appears to be maintained by the local production of specific cellderived chemotactic factors that recruit inflammatory cells from the pulmonary micovasculature into the alveolar interstitium [10]. An array of cytokines and chemokines has been identified that exhibit chemotactic activity for monocytes, such as monocyte chemoattractant protein-1 (MCP-1). Recently, MCP-1 was found to be intensely expressed in lung tissue [11] and bronchoalveolar lavage (BAL) fluid of patients with interstitial lung disease [12]. Several studies described a monocyte-like phenotype of AMs in chronic inflammatory lung diseases, possibly reflecting the influx of blood monocytes and/or the emergence of a proinflammatory macrophage phenotype [13-17]. 
In this study, we used a flow cytometric approach to identify monocytic cells in the BAL fluid of control subjects and of patients with chronic inflammatory lung disease. By using a panel of monoclonal antibodies directed against the $\beta_{2}$-integrin $\mathrm{CD} 11 \mathrm{~b}$, the lipopolysaccharide (LPS) receptor CD14, the low-affinity receptor for immunoglobulin $\mathrm{G}$ (IgG) (Fc $\gamma$ RIII, CD16), and the major histocompatability complex (MHC) class II molecule human leucocyte antigen-DR (HLA-DR), we selectively characterized the immunophenotype of these cells. Based on the distinct electro-optical features of AMs and monocytes, we quantified the numbers of alveolar monocytelike cells and correlated the results with lung function parameters.

\section{Methods}

\section{Study population}

A total of 77 nonsmoking patients with chronic inflammatory lung disease were studied. BAL fluid was obtained from 19 patients with sarcoidosis ( 7 males and 12 females; mean age $43 \pm 3$ yrs), 29 patients with idiopathic pulmonary fibrosis (IPF) (13 males and 16 females; mean age $53 \pm 2 \mathrm{yrs}$ ), 10 patients suffering from extrinsic allergic alveolitis (EAA) ( 7 males and 3 females; mean age $43 \pm 3$ yrs), and 19 patients ( 9 males and 10 females; mean age $51 \pm 2 \mathrm{yrs}$ ) with pulmonary involvement by collagen vascular diseases (CVD). The diagnosis of sarcoidosis,
IPF, EAA and CVD was based upon clinical and radiological findings, as well as on pulmonary function tests and positive findings in histological examinations of transbronchial biopsy specimens. A total of 16 patients (three with sarcoidosis, eleven with IPF, one with EAA, and one with CVD) were receiving maintenance prednisone therapy $\left(7.5-15 \mathrm{mg}^{\left.-\mathrm{day}^{-1}\right)}\right.$ for a period of at least 4 weeks prior to BAL.

The control group consisted of 10 nonsmoking volunteers (10 males; mean age $26 \pm 1$ yrs) without pulmonary disease, who underwent fibreoptic bronchoscopy and BAL for the purpose of this study. Results of lung function tests (table 1) and differential cell counts in the BAL fluid (table 2) were within the normal range in all control subjects. They were not under therapy at the time of the study.

The study protocol was approved by the institutional Ethical Committee. Informed consent was obtained from all control subjects and patients.

\section{Lung function tests}

Vital capacity (VC) was determined using a standard spirometer (Jaeger, Würzburg, Germany). The carbon monoxide transfer factor of the lung $(T \mathrm{~L}, \mathrm{CO})$ was measured by a single-breath method using a gas mixture containing $0.15 \% \mathrm{CO}$ and $4 \%$ helium. Blood gas analyses, including arterial oxygen tension $\left(\mathrm{Pa}_{\mathrm{a}} \mathrm{O}_{2}\right)$, arterial carbon dioxide tension $\left(\mathrm{Pa}_{\mathrm{a}} \mathrm{CO}_{2}\right)$, and $\mathrm{pH}$, were performed in arterialized capillary blood from the ear, at rest and during

Table 1. - Lung function characteristics of control subjects and patients

\begin{tabular}{|c|c|c|c|c|c|}
\hline & $\begin{array}{l}\text { Control } \\
\text { subjects } \\
(n=10)\end{array}$ & $\begin{array}{l}\text { Patients with } \\
\text { sarcoidosis } \\
(\mathrm{n}=19)\end{array}$ & $\begin{array}{c}\text { Patients with } \\
\text { IPF } \\
(n=29)\end{array}$ & $\begin{array}{c}\text { Patients with } \\
\text { EAA } \\
(\mathrm{n}=10)\end{array}$ & $\begin{array}{c}\text { Patients with } \\
\text { CVD } \\
(\mathrm{n}=19)\end{array}$ \\
\hline VC \% pred & $109 \pm 2$ & $107 \pm 5$ & $79 \pm 5 *$ & $91 \pm 9 *$ & $73 \pm 5^{*}$ \\
\hline$T \mathrm{~L}, \mathrm{CO} \%$ pred & $109 \pm 5$ & $96 \pm 6$ & $62 \pm 4 *$ & $73 \pm 4 *$ & $69 \pm 5^{*}$ \\
\hline \multirow{2}{*}{$\begin{array}{ll}\text { Resting } \mathrm{Pa}_{2} \mathrm{O}_{2} & \begin{array}{l}\mathrm{kPa} \\
\mathrm{mmHg}\end{array}\end{array}$} & $11.8 \pm 0.2$ & $11.1 \pm 0.3$ & $9.2 \pm 0.2 *$ & $10.5 \pm 0.5$ & $10.5 \pm 0.2 *$ \\
\hline & $88.7 \pm 1.7$ & $83.6 \pm 2.0$ & $69.0 \pm 1.7 *$ & $79.1 \pm 3.9$ & $79.1 \pm 1.3 *$ \\
\hline \multirow{2}{*}{ Exercise $\begin{array}{rl}\mathrm{Pa}_{\mathrm{a}} \mathrm{O}_{2} & \mathrm{kPa} \\
\mathrm{mmHg}\end{array}$} & ND & $10.8 \pm 0.4$ & $8.6 \pm 0.4$ & $9.1 \pm 0.4$ & $10.0 \pm 0.5$ \\
\hline & ND & $80.8 \pm 2.7$ & $64.5 \pm 3.3$ & $68.0 \pm 2.9$ & $75.1 \pm 3.6$ \\
\hline
\end{tabular}

Data are presented as mean \pm SEM. IPF: idiopathic pulmonary fibrosis; EAA: extrinsic allergic alveolitis; CVD: collagen vascular disease; VC: vital capacity; TL,CO: transfer factor of the lung for carbon monoxide; $\%$ pred: percentage of predicted value; $P \mathrm{a}_{2} \mathrm{O}_{2}$ : arterial oxygen tension; ND: not determined. *: $\mathrm{p}<0.05$ versus control value.

Table 2. - BAL fluid cellular constituents in control subjects and patients

\begin{tabular}{|c|c|c|c|c|c|}
\hline & $\begin{array}{l}\text { Control } \\
\text { subjects } \\
(n=10)\end{array}$ & $\begin{array}{l}\text { Patients with } \\
\text { sarcoidosis } \\
(n=19)\end{array}$ & $\begin{array}{c}\text { Patients with } \\
\text { IPF } \\
(n=29)\end{array}$ & $\begin{array}{c}\text { Patients with } \\
\text { EAA } \\
(\mathrm{n}=10)\end{array}$ & $\begin{array}{c}\text { Patients with } \\
\text { CVD } \\
(\mathrm{n}=19)\end{array}$ \\
\hline Total cells $\times 10^{6}$ & $6.5 \pm 1.5$ & $16.0 \pm 3.6^{*}$ & $15.5 \pm 2.2 *$ & $33.7 \pm 13.3^{*}$ & $10.5 \pm 1.2^{*}$ \\
\hline Cells $\cdot \mathrm{mL}^{-1}$ BAL fluid $\times 10^{4}$ & $12.1 \pm 2.3$ & $33.5 \pm 6.5^{*}$ & $36.1 \pm 4.9 *$ & $58.5 \pm 19.5 *$ & $21.3 \pm 2.0 *$ \\
\hline Macrophages \% & $93 \pm 2$ & $80 \pm 4 *$ & $70 \pm 4 *$ & $50 \pm 5^{*}$ & $85 \pm 3 *$ \\
\hline cells $\cdot \mathrm{mL}^{-1} \times 10^{4}$ & $11.3 \pm 2.8$ & $27.6 \pm 6.3^{*}$ & $22.5 \pm 2.8^{*}$ & $27.4 \pm 8.6^{*}$ & $17.8 \pm 1.7 *$ \\
\hline \multirow[t]{2}{*}{ Lymphocyes } & $5 \pm 1$ & $19 \pm 4 *$ & $21 \pm 4 *$ & $25 \pm 5^{*}$ & $6 \pm 1$ \\
\hline & $0.5 \pm 0.1$ & $5.5 \pm 1.4 *$ & $10.2 \pm 3.7 *$ & $15.9 \pm 6.2 *$ & $1.2 \pm 0.2 *$ \\
\hline \multirow[t]{2}{*}{ Granulocytes } & $2 \pm 1$ & $2 \pm 0$ & $8 \pm 1$ & $24 \pm 6^{*}$ & $10 \pm 2 *$ \\
\hline & $0.2 \pm 0.1$ & $0.4 \pm 0.1$ & $2.9 \pm 0.7 *$ & $14.9 \pm 6.8^{*}$ & $2.2 \pm 0.5 *$ \\
\hline
\end{tabular}

Data are presented as mean \pm SEM. BAL: bronchoalveolar lavage. For further definitions see legend to table 1 . *: $\mathrm{p}<0.05$ versus control value. 
steady-state exercise. Lung volumes were compared with the European Coal and Steel Community normal values [18]. The CO transfer factor was expressed as a percentage of our laboratory reference values [19].

\section{Bronchoalveolar lavage}

Fibreoptic bronchoscopy with BAL was performed as described previously [20]. A flexible fibreoptic bronchoscope was wedged into a subsegmental bronchus of the middle lobe or lingula, and five $20 \mathrm{~mL}$ aliquots of sterile saline solution $(0.9 \% \mathrm{NaCl})$ were infused and immediately aspirated. The recovered BAL fluid was pooled, filtered through two layers of sterile cotton gauze, and centrifuged at $300 \times \mathrm{g}$ for $10 \mathrm{~min}$. The cell pellet was washed twice, resuspended in phosphate-buffered saline (PBS), and the total cell counts were measured using a standard haemacytometer (Coulter Electronics, Krefeld, Germany). Cell viability was assessed by the trypan blue exclusion technique. Cytocentrifuge smears $(500 \mathrm{rpm} \times 5 \mathrm{~min})$ served to identify the cellular populations after staining with May-Grünwald-Giemsa. A total of 300 cells were counted to determine the percentages of alveolar macrophages, lymphocytes, neutrophils, eosinophils and mast cells.

\section{Processing of BAL cells for flow cytometry}

Surface antigen expression was determined by direct immunofluorescence applying the following panel of fluorescein isothiocyanate (FITC) or phycoerythrin (PE) conjugated monoclonal antibodies (Becton Dickinson, Heidelberg, Germany): anti-CD11b (Leu-15), anti-CD14 (Leu-M3), anti-CD16 (Leu-11c), and anti-HLA-DR. To estimate the amount of nonspecific binding of mouse monoclonal antibodies to human cell surface antigens, in particular that caused by Fc receptors, the cells were also incubated with irrelevant mouse monoclonal antibodies of $\mathrm{IgG}_{1}$ or $\mathrm{IgG}_{2 \alpha}$ isotype. For removal of contaminating erythrocytes and fixation of cells, a commercially available lysing solution (FACS Lysing Solution, Becton Dickinson) was used. Incubation with monoclonal antibodies and flow cytometry was performed as described previously $[21,22]$. Briefly, cell density was adjusted to $1 \times 10^{6}$ cells $\cdot \mathrm{mL}^{-1}$, and $100 \mu \mathrm{L}$ of the suspension was incubated with saturating amounts of conjugated monoclonal antibodies for $30 \mathrm{~min}$ at $4^{\circ} \mathrm{C}$, in the dark. Cells were fixed and contaminating erythrocytes were removed by addition of $1 \mathrm{~mL}$ of the lysing solution for $10 \mathrm{~min}$. The samples were centrifuged, washed and resuspended in PBS before flow cytometric analysis was performed.

\section{Flow cytometry}

All data were obtained using a fluorescence-activated cell sorter (FACS) Analyzer flow cytometer (Becton Dickinson, Heidelberg, Germany) equipped with a $\mathrm{Hg}$ Cd arc lamp, and a nozzle orifice of $75 \mu \mathrm{m}$. FITC and PE fluorescence signals were collected after excitation at $485 \pm 10 \mathrm{~nm}$ using standard band-pass filters $(530 / 30$ and 595/60). In general, a minimum of $10^{4}$ events was collected for each sample, and data were recorded in list mode on a Consort 30 data handling system (Becton Dickinson) and stored for later analysis. To ensure the comparability of the flow cytometric data over a prolonged period of time, the instrument setting of the flow cytometer was calibrated daily by using standard fluorescent microspheres.

The flow cytometer used in this study generates volume signals that are based on the Coulter-type measurement of electrical resistance. These signals are directly proportional to the volume of a particle/cell (as well as to its electrical resistance), in contrast to the forward scatter signal of other flow cytometers that is proportional to the cross-sectional area of a particle/cell (as well as to its refractive signal). This enabled us to calculate morphometric data, such as volume, diameter and surface area. To convert the arbitrary units of the Coultertype volume signals into geometric units, a calibration curve was generated by plotting the known diameters of a set of microsphere samples of five different particle sizes (Flow Cytometry Standards Corp., Research Triangle Park, NC, USA) against the corresponding volume signals.

The AM subpopulations were selectively analysed by electronic gating of volume side-scatter dot plots. Fluorescence histograms were used to calculate mean fluorescence intensities and to assess the percentages of positively stained cells. To overcome the problem of autofluorescence, the relative fluorescence intensity of a given sample was calculated by subtracting the signal obtained from cells incubated with the corresponding isotype control from the signal generated by cells that were incubated with the test antibody.

\section{Statistics}

Data were expressed as arithmetic means \pm standard error of the mean (SEM), except for the normal range of the percentage of BAL monocyte-like cells that was defined as the mean percentage of the control value $+2 \mathrm{SD}$. Multiple group comparisons were performed using Kruskal-Wallis analysis of variance (ANOVA) and MannWhitney rank sum test corrected by the Bonferroni method. Correlation coefficients were determined by Pearson's test. For differences between groups and correlation coefficients between variables, a two-tailed p-value of less than 0.05 was considered significant. The statistical computations were performed with the aid of the statistical package for the social sciences (SPSS)/PC+ statistical software.

\section{Results}

Functional characteristics of control subjects and patients with interstitial lung disease

The results of lung function tests in the control, sarcoidosis, IPF, EAA, and CVD groups are shown in table 1. There was a significant reduction of $\mathrm{VC}$ and $T \mathrm{~L}, \mathrm{CO}$ in patients with IPF, EAA and CVD, when compared with the control group. Patients with sarcoidosis did not 
differ significantly from the control group. $\mathrm{Pa}, \mathrm{O}_{2}$ values at rest were significantly reduced in patients with IPF and CVD.

\section{Total and differential cell counts from BAL fluid}

BAL fluid recovery and BAL cell viability were within the normal range and comparable between the five groups

a)

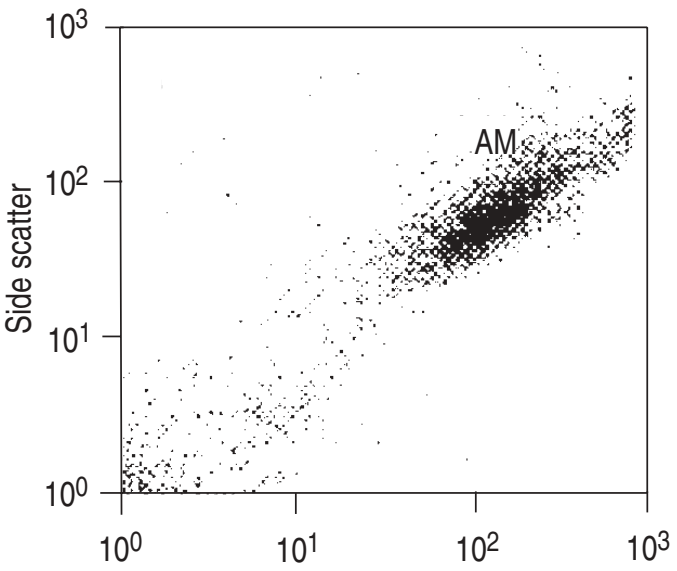

b)

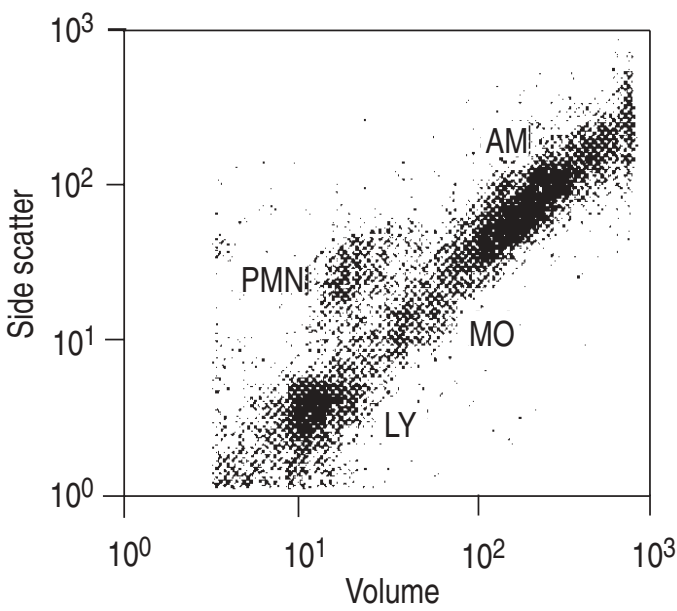

Fig. 1. - Flow cytometric volume side-scatter dot plots of BAL cells characteristic for: a) healthy control subject; and b) a patient with idiopathic pulmonary fibrosis. AM: alveolar macrophage; MO: monocytelike cells; PMN: granulocytes; LY: lymphocytes; BAL: bronchoalveolar lavage. (data not shown). The cell counts in the various disease groups and healthy volunteers are summarized in table 2. The total number of BAL cells recovered was significantly increased in all disease groups as compared with healthy volunteers. The percentages of lymphocytes were elevated in the sarcoidosis, IPF and EAA groups, whilst the percentages of granulocytes were higher in the EAA and CVD groups. In all disease groups, the percentage of AMs was significantly lower than in the control group. However, because of the increased total BAL cell numbers, the absolute number of AMs was increased in all disease groups. Mast cells were found only in small numbers that did not differ significantly between the study groups.

\section{Flow cytometric data}

Figure 1 shows two characteristic volume side-scatter dot plots derived from flow cytometric analyses of BAL cells. Figure 1a demonstrates the normal picture of BAL cells from a healthy control subject featuring a homogeneous population of predominantly large cells with considerable granularity (as defined by light-scattering properties), corresponding to the normal "large" AM population. Figure $1 \mathrm{~b}$, in contrast, shows the characteristic finding in a patient with chronic inflammatory lung disease. In addition to increased lymphocyte and granulocyte numbers, two distinct subpopulations of macrophages can be observed, i.e. a subpopulation of normal, "large" AM, along with a well-defined subpopulation of smaller monocyte-like cells. The electro-optical characteristics of the latter proved to be almost identical to those of blood monocytes (data not shown).

To further analyse these cell populations, firstly a gate that included the entire AM population ("large" AM and monocyte-like cells) was applied. As shown in table 3, a tendency to lower expression of HLA-DR and CD16, and to increased expression of CD11b and CD14 on the surface of AMs was observed in most of the disease groups compared to the control group. Due to the large number of group comparisons and also because of high interindividual variations, however, statistical significance $(\mathrm{p}<0.05)$ was only reached for the increased CD11b intensity and the elevated percentage of CD14 positive AM in EAA patients, for the decreased percentage of CD16 positive cells in IPF and CVD patients, for the reduced

Table 3. - Surface antigen expression on the total alveolar macrophage population

\begin{tabular}{|c|c|c|c|c|c|c|}
\hline & & $\begin{array}{l}\text { Control } \\
\text { subjects } \\
(n=10)\end{array}$ & $\begin{array}{l}\text { Patients with } \\
\text { sarcoidosis } \\
\quad(n=19)\end{array}$ & $\begin{array}{c}\text { Patients with } \\
\text { IPF } \\
(n=29)\end{array}$ & $\begin{array}{c}\text { Patients with } \\
\text { EAA } \\
(\mathrm{n}=10)\end{array}$ & $\begin{array}{c}\text { Patients with } \\
\text { CVD } \\
(\mathrm{n}=19)\end{array}$ \\
\hline CD11b & $\begin{array}{l}\% \\
\text { FI }\end{array}$ & $\begin{array}{c}52 \pm 5 \\
117 \pm 14\end{array}$ & $\begin{array}{c}72 \pm 9 \\
201 \pm 32\end{array}$ & $\begin{array}{c}70 \pm 5 \\
219 \pm 31\end{array}$ & $\begin{array}{c}76 \pm 5 \\
267 \pm 26^{*}\end{array}$ & $\begin{array}{c}48 \pm 4 \\
128 \pm 19\end{array}$ \\
\hline CD14 & $\begin{array}{l}\% \\
\text { FI }\end{array}$ & $\begin{array}{l}23 \pm 3 \\
56 \pm 5\end{array}$ & $\begin{array}{l}32 \pm 6 \\
69 \pm 8\end{array}$ & $\begin{array}{l}37 \pm 4 \\
97 \pm 18\end{array}$ & $\begin{array}{r}48 \pm 8^{*} \\
101 \pm 15\end{array}$ & $\begin{array}{l}24 \pm 3 \\
62 \pm 7\end{array}$ \\
\hline CD16 & $\begin{array}{l}\% \\
\text { FI }\end{array}$ & $\begin{array}{c}83 \pm 3 \\
267 \pm 26\end{array}$ & $\begin{array}{c}63 \pm 7 \\
154 \pm 25^{*}\end{array}$ & $\begin{array}{c}41 \pm 5^{*} \\
107 \pm 18^{*}\end{array}$ & $\begin{array}{c}55 \pm 9 \\
173 \pm 40\end{array}$ & $\begin{array}{c}50 \pm 7 * \\
112 \pm 16^{*}\end{array}$ \\
\hline HLA-DR & $\begin{array}{l}\% \\
\text { FI }\end{array}$ & $\begin{array}{c}92 \pm 1 \\
587 \pm 17\end{array}$ & $\begin{array}{c}89 \pm 3 \\
552 \pm 42\end{array}$ & $\begin{array}{c}84 \pm 2 \\
455 \pm 27\end{array}$ & $\begin{array}{r}70 \pm 8^{*} \\
380 \pm 53\end{array}$ & $\begin{array}{c}80 \pm 5 \\
434 \pm 49\end{array}$ \\
\hline
\end{tabular}

Data are presented as mean \pm SEM. \%: percentage of positively stained cells; FI: relative fluorescence intensity; HLA-DR: human leucocyte antigen-DR. For further definitions see legend to table 1 . *: $\mathrm{p}<0.05$ versus control value. 
Table 4. - Comparison of morphometric and immunophenotypic features of alveolar monocyte-like cells and "large" AMs

\begin{tabular}{llccl}
\hline & & $\begin{array}{c}\text { Monocyte- } \\
\text { like cells } \\
(\mathrm{n}=87)\end{array}$ & $\begin{array}{c}\text { "Large" AMs } \\
(\mathrm{n}=87)\end{array}$ & $\mathrm{p}$-value \\
\hline Diameter & $\mu \mathrm{m}$ & $12.3 \pm 0.1$ & $19.5 \pm 0.3$ & $<0.001$ \\
Surface area $\mu \mathrm{m}^{2}$ & $476 \pm 9$ & $1213 \pm 31$ & $<0.001$ \\
$\mathrm{CD} 11 \mathrm{~b}$ & $\%$ & $76 \pm 2$ & $66 \pm 4$ & $<0.02$ \\
& FI & $118 \pm 11$ & $184 \pm 17$ & $<0.001$ \\
& FD & $0.23 \pm 0.02$ & $0.14 \pm 0.01$ & $<0.001$ \\
$\mathrm{CD} 14$ & $\%$ & $64 \pm 2$ & $34 \pm 3$ & $<0.001$ \\
& FI & $78 \pm 6$ & $79 \pm 8$ & $>0.05$ \\
& FD & $0.17 \pm 0.01$ & $0.07 \pm 0.01$ & $<0.001$ \\
CD16 & $\%$ & $63 \pm 2$ & $65 \pm 3$ & $>0.05$ \\
& FI & $43 \pm 5$ & $174 \pm 14$ & $<0.001$ \\
& FD & $0.09 \pm 0.01$ & $0.15 \pm 0.01$ & $<0.001$ \\
HLA-DR & $\%$ & $86 \pm 1$ & $92 \pm 2$ & $<0.001$ \\
& FI & $190 \pm 11$ & $550 \pm 21$ & $<0.001$ \\
& FD & $0.41 \pm 0.02$ & $0.49 \pm 0.04$ & $<0.02$ \\
\hline
\end{tabular}

Data are presented as mean \pm SEM. \%: percentage of positively stained cells; AMs: alveolar macrophages; FI: relative fluorescence intensity (mean channel fluorescence); FD: fluorescence density (relative FI. $\mathrm{mm}^{-2}$ cell surface); HLA-DR: human leucocyte antigen-DR.

CD16 staining intensity in patients with sarcoidosis, IPF and CVD, and for the decreased expression of HLA-DR molecules on AM from patients with EAA.

Secondly, the two AM populations ("large" AM and monocyte-like cells) were selectively gated and their morphometric and immunophenotypic features were compared (table 4). Monocyte-like cells and "large" AM had mean diameters of $12.3 \pm 0.1$ and $19.5 \pm 0.3 \mu \mathrm{m}$, respectively, and a mean surface area of $476 \pm 9$ and $1213 \pm 31$ $\mu \mathrm{m}^{2}$, respectively. Whilst expression of HLA-DR was found to be significantly higher on "large" AMs, expression of CD14 and CD11b proved to be significantly higher on monocyte-like cells. No significant difference was found for the percentage of CD16 positive cells. When comparing the relative fluorescence intensities as a measure of the overall number of binding sites on the cell surface, "large" AMs expressed a threefold higher number of HLA-DR antigens, a fourfold higher number of CD16 molecules, and 1.5 fold more CD11b surface epitopes, as compared to monocyte-like cells. However, no statistical difference was found for the fluorescence intensity of CD14-labelled cells (table 4).

To evaluate whether the observed differences in the expression of surface molecules were simply due to differences in the size of the surface area of the two macrophage populations, the relative fluorescence density of surface molecules, i.e. the relative fluorescence intensity $(\mathrm{FI}) \cdot \mu \mathrm{m}^{-2}$ cell surface, was calculated. These calculations revealed that HLA-DR (1.2 fold) and CD16 (1.7 fold) molecules were expressed with a higher density on the surface of "large" AMs, while the density of CD11b (1.6 fold) and CD14 (2.4 fold) molecules was higher on the surface of monocyte-like cells.

Next, the percentage and the total numbers of BAL monocyte-like cells $\cdot \mathrm{mL}^{-1}$ BAL fluid were assessed by counting the numbers of cells included in the two macrophage gates, calculating the percentage of monocyte-like
Table 5. - Correlations of numbers of alveolar monocyte-like cells with lung function parameters and expression of surface antigens on total AMs

\begin{tabular}{lcc}
\hline Parameter & $\begin{array}{c}\text { Correlation } \\
\text { coefficient }\end{array}$ & p-value \\
\hline TL,CO \% pred & -0.42 & $<0.001$ \\
Resting $P$ a, $\mathrm{O}_{2} \mathrm{mmHg}$ & -0.43 & $<0.001$ \\
$\mathrm{CD} 11 \mathrm{~b}+\mathrm{AM} \%$ & 0.42 & $<0.01$ \\
$\mathrm{CD} 14+\mathrm{AM} \%$ & 0.63 & $<0.001$ \\
$\mathrm{CD} 16+\mathrm{AM} \%$ & -0.49 & $<0.001$ \\
HLA-DR+ AM \% & -0.65 & $<0.001$
\end{tabular}

For definitions see legends to tables 1 and 3.

cells within the entire AM population, and transferring these data to the conventional BAL differential and total cell counts. According to these calculations, the percentage of BAL monocyte-like cells was $9 \pm 1 \%$ in control subjects, $13 \pm 2 \%$ in patients with sarcoidosis, $16 \pm 1 \%$ in patients with IPF ( $\mathrm{p}<0.05$ versus control subjects), $15 \pm$ $3 \%$ in patients with EAA, and $16 \pm 2 \%$ in patients with CVD ( $p<0.05$ versus control subjects). The total number of monocyte-like cells $\cdot \mathrm{mL}^{-1} \mathrm{BAL}$ fluid was significantly $(p<0.05)$ increased in all disease groups, with $3.5 \pm 0.6$ $\times 10^{4}$ cells $\cdot \mathrm{mL}^{-1}$ in patients with sarcoidosis, $5.4 \pm 0.6 \times 10^{4}$ cells $\cdot \mathrm{mL}^{-1}$ in patients with IPF, $8.3 \pm 2.5 \times 10^{4}$ cells $\cdot \mathrm{mL}^{-1}$ in patients with EAA, and $3.5 \pm 0.6 \times 10^{4}$ cells $\cdot \mathrm{mL}^{-1}$ in patients with CVD, as compared to only $1.0 \pm 0.1 \times 10^{4}$ cells $\cdot \mathrm{mL}^{-1}$ in control subjects. Whilst negative correlations were found between numbers of monocyte-like cells and expression of the macrophage-associated surface receptors CD16 and HLA-DR on the total AM population, positive correlations were calculated between monocyte numbers and total expression of the monocyteassociated surface antigens CD11b and CD14 (table 5). Most interestingly, a close relationship was also detected between monocyte numbers and lung function parameters (table 5).

Finally, all patients, irrespective of their diagnosis, were assigned to two groups according to whether the calculated percentage of BAL fluid monocyte-like cells was lower or higher than $13 \%$ (=mean value of the control group $+2 \mathrm{SD}$ ). As shown in table 6, high percentage of these cells in the BAL fluid $(>13 \%)$ was associated with reduced $\mathrm{VC}$, and impaired gas exchange, as assessed by measurements of $T \mathrm{~L}, \mathrm{CO}$, resting $\mathrm{Pa}_{\mathrm{a}} \mathrm{O}_{2}$, and exercise $\mathrm{Pa}, \mathrm{O}_{2}$.

Table 6. - Comparison of lung function findings in patients with high or low percentage of alveolar monocyte-like cells

\begin{tabular}{|c|c|c|c|c|}
\hline & & $\begin{array}{c}\text { Group A } \\
<13 \% \\
\text { monocytes } \\
\text { in BALF }\end{array}$ & $\begin{array}{c}\text { Group B } \\
>13 \% \\
\text { monocytes } \\
\text { in BALF }\end{array}$ & p-value \\
\hline VC \% pred & & $96 \pm 4$ & $80 \pm 4$ & $<0.05$ \\
\hline$T \mathrm{~L}, \mathrm{CO} \%$ pred & & $84 \pm 4$ & $64 \pm 3$ & $<0.005$ \\
\hline Resting $\mathrm{Pa}_{\mathrm{a}} \mathrm{O}_{2}$ & $\mathrm{kPa}$ & $\begin{array}{l}11.0 \pm 0.2 \\
827+12\end{array}$ & $\begin{array}{r}9.6 \pm 0.2 \\
718+17\end{array}$ & $<0.001$ \\
\hline Exercise $P \mathrm{a}, \mathrm{O}_{2}$ & $\begin{array}{l}\mathrm{kPa} \\
\mathrm{mmHg}\end{array}$ & $\begin{array}{l}10.2 \pm 0.4 \\
76.8 \pm 2.7\end{array}$ & $\begin{array}{r}9.1 \pm 0.3 \\
67.9 \pm 2.6\end{array}$ & $<0.01$ \\
\hline
\end{tabular}

Data are presented as mean \pm SEM. BALF: bronchoalveolar lavage fluid. For further definitions see legend to table 1. 


\section{Discussion}

Alveolar macrophages have been described as a heterogeneous population with respect to morphology, immunophenotype and function. Subpopulations of AMs were identified in the lungs of normal rats [23-25], guineapigs [26], rabbits [27], and humans [3, 5, 28, 29]. Several experimental studies have suggested that resident AM populations in the normal lung are maintained by local division of cells and that the influx of peripheral monocytes is not needed to sustain the AM population $[6,30$, 31]. In contrast, Bowden and ADAMSON [7] postulated that under normal circumstances the predominant mechanism of macrophage production is direct passage of monocytes across the interstitium to the alveoli, and that only a smaller proportion of cells appears to arise after division of resident interstitial cells with subsequent migration to the alveoli.

Kinetic studies after carbon loading in mice have suggested an acceleration of the normal dual mechanism, whereby most cells are derived from monocytes crossing the interstitium without division and a smaller proportion arising by division of interstitial cells with migration to the alveoli [8]. Further animal studies have demonstrated that the increase of the pulmonary macrophage population during an acute inflammation is brought about mainly by monocyte influx and to a minor extent by temporarily increased local production of macrophages [9]. Consequently, the appearance of small monocyte-like AMs was described in further experimental studies both of acute [32] and chronic [22] lung inflammation. However, local macrophage replication may also play a role in the expansion of the AM population in chronic lung inflammation [33, 34].

There is a growing body of evidence that an increased recruitment of monocytes also takes place in human interstitial and other lung diseases. An elevated expression of monocyte-lineage surface antigens was found on AMs from patients with sarcoidosis [13, 14, 17, 35-38], idiopathic pulmonary fibrosis $[15,16,36-38]$, extrinsic allergic alveolitis [36, 37], bronchogenic carcinoma [35], asthma [39], human immunodeficiency virus (HIV) infection [40], as well as in smoking individuals [41, 42]. The increased expression of binding sites for several lectins by AMs from patients with interstitial lung disease may reflect the influx of immature blood monocytes and/or the emergence of a proinflammatory macrophage phenotype [43]. In a recently published study, however, the authors postulated that the majority of AMs recovered by BAL in sarcoidosis are mature, activated cells [44].

To characterize the AM subsets in the present study, we used a panel of monoclonal antibodies directed against CD11b, CD14, CD16, and HLA-DR surface molecules on AMs. CD11b is the $\alpha$-chain of a $\beta_{2}$-integrin that is expressed at high levels on blood monocytes [36], quantitatively upregulated on the surface of fresh extravasated monocytes [45], and expressed at only low levels on mature AMs [35]. CD14 is a receptor for LPS that is expressed at high levels in normal blood monocytes, and at low levels in the subset of CD14+/CD16+ monocytes, as well as in mature AMs [46, 47]. CD16, the low-affinity receptor for $\operatorname{IgG}(\mathrm{Fc} \gamma \mathrm{RIII})$, in contrast, is expressed at only low levels on blood monocytes, but is highly expressed on end-stage differentiated macrophages [47]. The MHC class II molecule HLA-DR has been shown to be expressed both on blood monocytes and AMs, with a considerably higher staining intensity in AMs [48].

The results presented here confirm the findings reported by others in patients with chronic inflammatory lung disease, i.e. a monocyte-like immunophenotype of the total AM population, displaying increased expression of CD14 [13, 14, 17, 35] and CD11b [35, 38], and reduced expression of CD16. Our quantitative flow cytometric analyses, however, extend these findings in that they demonstrate that in the BAL fluid of patients with chronic inflammatory lung disease increased numbers of monocyte-like cells can be identified that exhibit the electrooptical characteristics of blood monocytes and an immunophenotype intermediate between blood monocytes and AMs. The close positive correlations between numbers of monocyte-like cells and expression of monocyteassociated (CD11b, CD14) antigens, as well as the inverse correlations between monocyte numbers and macrophageassociated antigens (CD16, HLA-DR) on the surface of the total AM population provide further evidence for an exaggerated monocyte influx. When calculating the densities of antibody binding sites, we found that alveolar monocyte-like cells express significantly higher numbers of CD11b and CD14 receptors per unit, and significantly lower numbers of CD16 and HLA-DR molecules per unit compared to mature AMs. Taken together, these data strongly suggest that blood monocytes recruited from the pulmonary microvasculature to the bronchoalveolar space are likely to be responsible for the observed alterations in surface molecule expression on the total alveolar monocyte/macrophage population.

Interestingly, we detected a considerable percentage of monocyte-like cells $(9 \pm 1 \%)$ in the BAL fluid of control subjects. The monocyte chemoattractant MCP-1 has been shown to be present in the BAL fluid of healthy control subjects [12]. Thus, MCP-1 produced by normal AMs or alveolar type II epithelial cells may, in part, be responsible for the maintenance of the AM population under noninflammatory conditions. In chronic inflammatory lung disease, however, high numbers of monocytelike cells are closely associated with impaired lung function, as indicated by the results presented here.

In summary, this study extends previous findings regarding the immature phenotype of the alveolar macrophage in chronic inflammatory lung disease. Our quantitative flow cytometric data confirm the appearance of increased numbers of alveolar monocyte-like cells in the patients' bronchoalveolar lavage fluid, suggesting that in human chronic inflammatory lung disease considerable numbers of monocytes are recruited into the bronchoalveolar space. The sequence of events leading to a "monocytic alveolitis", such as monocyte-endothelium cell interactions, transmigration through the endothelial layer, migration through the pulmonary interstitium, including various cell-matrix interactions, and, finally, emigration into the alveolar space, may play a key role in the pathogenesis of interstitial lung diseases. Accumulation of these inflammatory cells in the lungs of patients with chronic inflammatory lung disease may, in turn, contribute to the disease process by virtue of exaggerated production of oxidants, cytokines and other mediators. 
Acknowledgements: The authors wish to thank AM. Allmeling and S. Münzing for their expertise and excellent technical assistance.

\section{References}

1. Crystal RG, Gadek JE, Ferrans VJ, Fulmer JD, Line BR, Hunninghake GW. Interstitial lung disease: current concepts of pathogenesis, staging and therapy. Am J Med 1981; 70: 542-568.

2. Sibille Y, Reynolds HY. Macrophages and polymorphonuclear neutrophils in lung defense and injury. $A m$ Rev Respir Dis 1990; 141: 471-501.

3. Calhoun WJ, Salisbury SM. Heterogeneity in cell recovery and superoxide production in buoyant, density-defined subpopulations of human alveolar macrophages from healthy volunteers and sarcoidosis patients. J Lab Clin Med 1989; 114: 682-690.

4. Gant VA, Hamblin AS. Human bronchoalveolar macrophage heterogeneity demonstrated by histochemistry, surface markers and phagocytosis. Clin Exp Immunol 1985; 60: 539-545.

5. Sandron D, Reynolds HY, Venet A, Laval AM, IsraelBiet D, Chretien J. Human alveolar macrophage subpopulations isolated on discontinuous albumin gradients: functional data in normals and sarcoid patients. Eur $J$ Respir Dis 1986; 69: 226-234.

6. Shellito J, Esparza C, Armstrong C. Maintenance of the normal rat alveolar macrophage cell population: the roles of monocyte influx and alveolar macrophage proliferation in situ. Am Rev Respir Dis 1987; 135: 78-82.

7. Bowden DH, Adamson IYR. Role of monocytes and interstitial cells in the generation of alveolar macrophages. I. Kinetic studies of normal mice. Lab Invest 1980; 42: 511-517.

8. Adamson IYR, Bowden DH. Role of monocytes and interstitial cells in the generation of alveolar macrophages. II. Kinetic studies after carbon loading. Lab Invest 1980; 42: $518-524$.

9. Blussé van Oud Alblas A, van der Linden-Schrever B, van Furth R. Origin and kinetics of pulmonary macrophages during an inflammatory reaction induced by intravenous administration of heat-killed bacillus CalmetteGuérin. J Exp Med 1981; 154: 235-252.

10. Schleimer RP, Benenati SV, Friedman B, Bochner BS. Do cytokines play a role in leukocyte recruitment and activation in the lungs? Am Rev Respir Dis 1991; 143: 1169-1174.

11. Antoniades HN, Neville-Golden J, Galanopoulos T, Kradin R, Valente AJ, Graves DT. Expression of monocyte chemotactic protein 1 mRNA in human idiopathic fibrosis. Proc Natl Acad Sci USA 1992; 89: 5371-5375.

12. Car BD, Meloni F, Luisetti M, Semenzato G, GialdroniGrassi G, Walz A. Elevated IL-8 and MCP-1 in the bronchoalveolar lavage fluid of patients with idiopathic pulmonary fibrosis and pulmonary sarcoidosis. Am J Respir Crit Care Med 1994; 149: 655-659.

13. Hance AJ, Douches S, Winchester RJ, Ferrans VJ, Crystal RG. Characterization of mononuclear phagocyte subpopulations in human lung by using monoclonal antibodies: changes in alveolar macrophage phenotype associated with pulmonary sarcoidosis. J Immunol 1985 ; 134: 284-292.

14. Agostini C, Garbisa S, Trentin L, et al. Pulmonary alveolar macrophages express type IV collagenolytic proteinase: an enzymatic mechanism for influx of mononuclear phagocytes at sites of disease activity. $J$ Clin Invest 1989; 84: 605-612.

15. Hoogsteden HC, van Dongen JJM, van Hal PT, Delahaye M, Hop W, Hilvering C. Phenotype of blood monocytes and alveolar macrophages in interstitial lung disease. Chest 1989; 95: 574-577.

16. Kiemle-Kallee J, Kreipe H, Radzun H-J, et al. Alveolar macrophages in idiopathic pulmonary fibrosis display a more monocyte-like immunophenotype and an increased release of free oxygen radicals. Eur Respir J 1991; 4: 400-406.

17. Pforte A, Schiessler A, Gais P, et al. Expression of CD14 correlates with lung function impairment in pulmonary sarcoidosis. Chest 1994; 105: 349-354.

18. European Coal and Steel Community. Report of Working Party on Standardization of Lung Function Tests, Luxembourg. Bull Eur Physiopathol Respir 1983; 19 (Suppl. 5).

19. Behr J, Adelmann-Grill BC, Krombach F, Beinert T, Schwaiblmair M. Fruhmann G. Fibroblast chemotactic response elicited by native bronchoalveolar lavage fluid from patients with fibrosing alveolitis. Thorax 1993; 48: 736-742.

20. Behr J, Maier K, Krombach F, Adelmann-Grill BC. Pathogenetic significance of reactive oxygen species in diffuse fibrosing alveolitis. Am Rev Respir Dis 1991; 144: $146-150$.

21. Padovan C, Behr J, Allmeling A-M, Gerlach JT, Vogelmeier C, Krombach FP. Immunophenotyping of Iymphocyte subsets in bronchoalveolar lavage fluid. J Immunol Methods 1992; 147: 27-32.

22. Hildemann S, Hammer C, Krombach F. Heterogeneity of alveolar macrophages in experimental silicosis. Environ Health Perspect 1992; 97: 53-57.

23. Shellito J, Kaltreider HB. Heterogeneity of immunologic function among subfractions of normal rat alveolar macrophages. Am Rev Respir Dis 1984; 129: 747-753.

24. Chandler DB, Fulmer JD. Prostaglandin synthesis and release by subpopulations of rat alveolar macrophages. J Immunol 1987; 139: 893-898.

25. Lehnert BE, Valdez YE, Fillak DA, Steinkamp JA, Stewart CC. Flow cytometric characterization of alveolar macrophages. J Leukocyte Biol 1986; 39: 285-298.

26. Holian A, Dauber JH, Diamond MS, Daniele RP. Separation of bronchoalveolar cells from the guinea-pig on continuous gradients of percoll: functional properties of fractionated lung macrophages. J Reticuloendothel Soc 1983; 33: 157-164.

27. Sitrin RG, Brubaker LW, Shellito JD, Kaltreider HB. The distribution of procoagulant and plasminogen activator activities among density fractions of normal rabbit alveolar macrophages. Am Rev Respir Dis 1986; 133: 469-472.

28. Campbell DA, Poulter LW, du Bois RM. Phenotypic analysis of alveolar macrophages in normal subjects and in patients with interstitial lung disease. Thorax 1986; 41: 429-434.

29. McDonald CF, Hutchinson P, Atkins RC. Delineation of pulmonary alveolar macrophage subpopulations by flow cytometry in normal subjects and in patients with lung cancer. Clin Exp Immunol 1993; 91: 126-130.

30. Sawyer RT. The significance of local resident pulmonary alveolar macrophage proliferation to population renewal. J Leukocyte Biol 1986; 39: 77-87.

31. Tarling JD, Lin H-S, Hsu S. Self-renewal of pulmonary alveolar macrophages: evidence from radiation chimera studies. J Leukocyte Biol 1987 42: 443-446. 
32. Rinaldo JE, Moore SA, Lee RE, Dauber JH. Shift in subfractions of alveolar macrophages in vivo during endotoxin-induced alveolitis. J Leukocyte Biol 1987; 42: 230-238.

33. Bitterman PB, Satzman LE, Adelberg S, Ferrans VJ, Crystal RG. Alveolar macrophage replication: one mechanism for the expansion of the mononuclear phagocyte population in the chronically inflamed lung. J Clin Invest 1984; 74: 460-469.

34. Pforte A, Gerth C, Voss A, et al. Proliferating alveolar macrophages in BAL and lung function changes in interstitial lung disease. Eur Respir J 1993; 6: 951-955.

35. Barbosa IL, Gant VA, Hamblin AS. Alveolar macrophages from patients with bronchogenic carcinoma and sarcoidosis similarly express monocyte antigens. Clin Exp Immunol 1991; 86: 173-178.

36. Hoogsteden HC, van Hal PTW, Wijkhuijs JM, Hop W, Hilvering C. Expression of the CD11/CD18 cell surface adhesion glycoprotein family and MHC class II antigen on blood monocytes and alveolar macrophages in interstitial lung diseases. Lung 1992; 170: 221-233.

37. Hoogsteden HC, van Hal PTW, Wijkhuijs JM, Hop W, Hilvering C. Difference in expression of monocyte/macrophage surface antigens in peripheral blood and bronchoalveolar lavage cells in interstitial lung diseases. Lung 1993; 171: 149-160.

38. Schaberg T, Rau M, Stephan H, Lode H. Increased number of alveolar macrophages expressing surface molecules of the CD11/CD18 family in sarcoidosis and idiopathic pulmonary fibrosis is related to the production of superoxide anions by these cells. Am Rev Respir Dis 1993; 147: 1507-1513.

39. Poulter LW, Norris A, Power C, Condez A, Schmekel B, Burke C. T-cell dominated inflammatory reactions in the bronchi of asthmatics are not reflected in matched bronchoalveolar lavage specimens. Eur Respir J 1992; 5: $182-189$.
40. Wassermann K, Subklewe M, Pothoff G, Banik N, SchellFrederick E. Expression of surface markers on macrophages from symptomatic patients with HIV infection as detected by flow cytometry. Chest 1994; 105: 1324-1334.

41. Hoogsteden HC, van Hal PTW, Wijkhuijs JM, Hop W, Verkaik APK, Hilvering C. Expression of the CD11/ CD18 cell surface adhesion glycoprotein family on alveolar macrophages in smokers and nonsmokers. Chest 1991; 100: 1567-1571.

42. Schaberg T, Lauer C, Lode H, Fischer J, Haller H. Increased number of alveolar macrophages expressing adhesion molecules of the leukocyte adhesion molecule family in smoking subjects: association with cell-binding ability and superoxide anion production. Am Rev Respir Dis 1992; 146: 1287-1293.

43. Meyer KC, Powers C, Rosenthal N, Auerbach R. Alveolar macrophage surface carbohydrate expression is altered in interstitial lung disease as determined by lectinbinding profiles. Am Rev Respir Dis 1993; 148: 1325-1334.

44. Striz I, Wang YM, Teschler H, Sorg C, Costabel U. Phenotypic markers of alveolar macrophage maturation in pulmonary sarcoidosis. Lung 1993; 171: 293-303.

45. Krombach F, Allmeling A-M, Messmer K. Inverse regulation of CD11b and L-selectin on lung infiltrating monocytes. Am Rev Respir Dis 1993; 147: A469. (Abstract)

46. Passlick B, Flieger D, Ziegler-Heitbrock HWL. Identification and characterization of a novel monocyte subpopulation in human peripheral blood. Blood 1989; 74:2527-2534.

47. Andreesen R, Brugger W, Scheibenbogen C, et al. Surface phenotype analysis of human monocyte to macrophage maturation. J Leukocyte Biol 1990; 47: 490-497.

48. Skold CM, Eklund A, Halldén G, Hed J. Different cell surface and phagocytic properties in mononuclear phagocytes from blood and alveoli: a comparative study of blood monocytes and alveolar macrophages from human nonsmokers using flow cytofluorometry. APMIS 1990; 98: 415-422. 